\title{
Diet and herding strategies in a changing environment: stable isotope analysis of Bronze Age and Late Antique skeletal remains from Ya'amūn, Jordan
}

Article

Accepted Version

Sandias, M. and Müldner, G. (2015) Diet and herding strategies in a changing environment: stable isotope analysis of Bronze Age and Late Antique skeletal remains from Ya'amūn, Jordan. Journal of Archaeological Science, 63. pp. 24-32. ISSN 0305-4403 doi:

https://doi.org/10.1016/j.jas.2015.07.009 Available at https://centaur.reading.ac.uk/42502/

It is advisable to refer to the publisher's version if you intend to cite from the work. See Guidance on citing.

Published version at: http://www.sciencedirect.com/science/article/pii/S030544031500237X

To link to this article DOI: http://dx.doi.org/10.1016/j.jas.2015.07.009

Publisher: Elsevier

All outputs in CentAUR are protected by Intellectual Property Rights law, including copyright law. Copyright and IPR is retained by the creators or other copyright holders. Terms and conditions for use of this material are defined in the End User Agreement. 


\section{www.reading.ac.uk/centaur}

\section{CentAUR}

Central Archive at the University of Reading

Reading's research outputs online 
1 Diet and herding strategies in a changing environment: stable isotope

2 analysis of Bronze Age and Late Antique skeletal remains from

3 Ya'amūn, Jordan

4 Michela Sandias $^{\mathrm{a}^{*}}$ and Gundula Müldner ${ }^{\mathrm{a}}$

$5 \quad{ }^{a}$ Department of Archaeology, University of Reading, Whiteknights PO Box 227, Reading, U.K.

6 * Corresponding Author. Present address: Via del Cestello 2/2, 40124, Bologna, Italy, email:

7 m.sandias@gmail.com

\section{Abstract}

10 Carbon and nitrogen stable isotope ratios of 45 human and 23 faunal bone collagen samples were

11 measured to study human diet and the management of domestic herbivores in past Jordan,

12 contrasting skeletal remains from the Middle and Late Bronze Age and the Late Roman and

13 Byzantine periods from the site of Ya'amūn near Irbid. The isotope data demonstrate that the

14 management of the sheep and goats changed over time, with the earlier animals consuming more

15 plants from semi-arid habitats, possibly because of transhumant herding strategies. The isotope

16 data for fish presented here are the first from archaeological contexts from the Southern Levant.

17 Although fish of diverse provenance was available at the site, human diet was predominately based

18 on terrestrial resources and there was little dietary variability within each time-period. Isotopic

19 variation between humans from different time-periods can mostly be explained by 'baseline shifts'

20 in the available food sources; however, it is suggested that legumes may have played a more

21 significant role in Middle and Late Bronze Age diet than later on.

22 Keywords: carbon and nitrogen isotopes; bone collagen; Bronze Age; Roman period; Byzantine

23 period; fish; 


\section{Highlights}

$25 \delta^{13} \mathrm{C}$ and $\delta^{15} \mathrm{~N}$ values were employed to reconstruct herd management and human diet in past Jordan Bronze Age ovicaprids consumed more plants from semi-arid habitats than Late Roman/Byzantine animals

The data suggest drier conditions or transhumant herd management in the Bronze Age

Differences in the human data can mostly be explained by environmental changes.

\section{Introduction}

The archaeology of the Near East is one of the areas where carbon and nitrogen isotope analysis has made a considerable impact in recent years, contributing, for example, to our understanding of early husbandry practices (Makarewicz and Tuross, 2012; Pearson et al., 2007;), the heterogeneous origins of people and animals (Hartman et al., 2013, Thompson et al. 2008), the contribution to human diet of specific food resources (Lösch, et al., 2006, Richards et al., 2003, Thompson et al., 2005) and the development of social complexity (Makarewicz, 2013, Pearson et al., 2013). One of the key strengths of the method is where it permits diachronic comparisons of isotope data from individual sites, enabling the tracing of continuity or change of subsistence strategies and environmental contexts through time. Using this approach, carbon stable isotope analysis of dental enamel of Bronze Age and Byzantine burials from the sites of $\mathrm{Ya}^{6} \mathrm{amūn}, \mathrm{Sa}{ }^{6}$ ad and Yasieleh in North Jordan suggested remarkable homogeneity in diet across time and sites (Al-Shorman, 2003, 2004). A complementary study of carbon and nitrogen stable isotope ratios in dentinal collagen of human teeth recovered from Ya'amūn, Sa'ad and Yasieleh also indicated continuity (King, 2001). Because of the samples chosen, both studies explored diet only over the relatively short period of 
tooth formation in childhood and early adolescence and the lack of site- and period-specific faunal baseline data did not allow monitoring for differences in environmental settings in this ecologically diverse region. Building on this previous research, the present study adds new evidence from carbon and nitrogen stable isotope analysis of bone collagen of human and faunal remains from Ya'amūn, in an attempt to reconstruct animal and human long-term adult diet at the site during two profoundly different time periods. We aim to explore how Bronze Age and Late Antiquity consumption profiles reflect changes in landscape exploitation and economic strategies, which are of great significance for understanding the way of life in northern Jordan in the past.

\section{The site of $\mathrm{Ya}^{6} \mathrm{amūn}$}

Jordan's territory is characterised by high variability in vegetation, physiography, hydrology, and climate. Four of the five vegetation regions identified in the Middle East, the Mediterranean region, the Irano-Turanian steppe, the Saharo-Arabian region and the Sudanian region are present in Jordan (Zohary, 1973; Palmer 2013, Figure 1a). Ya'amūn is located in the northern part of the Western Highlands at about eight hundred metres above sea level, $23 \mathrm{~km}$ southeast of Irbid. Here, current mean annual precipitation is $\sim 400 \mathrm{~mm}$ (Cordova, 2007). However, within few tens of kilometres of Ya'amūn the amount of rainfall decreases drastically to less than $200 \mathrm{~mm}$, with the dry Jordan River Valley to the west and the steppe and desert landscapes to the east (Figure 1b). The region

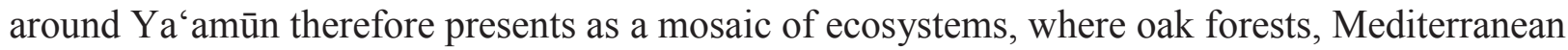
low vegetation and steppe habitats are in relative close proximity (Al-Eisawi, 1985).

Occupation at Ya'amūn spanned from the Early Bronze Age, beginning at c. 3600 cal BCE to the Ayyubid-Mamluk period, thirteenth to sixteenth century CE (dates as in Adams, 2008). Since the first season of excavation, several tombs of variable type, chamber and shaft tombs as well as natural caves used for burial have been identified and excavated (Renfro and Cooper, 2000, Rose, 2002, Rose et al., 2007, Rose et al., 2003). As most of these have been robbed in modern times 
and/or reused during the Islamic and later periods a detailed description of burial rites is not available (Rose, 2005). Excavations of the tombs and of the Bronze Age settlement have produced Mycenaean and Cypriot ceramic sherds, Egyptian scarabs and a Mittanian cylinder seal, which demonstrate trade and contact with different areas of the Mediterranean (Rose, 2001). During Late Antiquity (approx. $4^{\text {th }}-7^{\text {th }}$ century CE (Watson, 2008)), Ya'amūn was a thriving agricultural settlement which contributed to the evidently booming economy in the Late Roman and particularly the Byzantine period (Cameron, 1993, Freeman, 2008, Kennedy, 2007, Parker 1999, Rosen, 2007). The prosperity of Ya'amūn is shown by various olive and wine presses and by numerous carved water cisterns (El-Najjar and Rose, 2003, Rose et al., 2007). Furthermore, the mosaics of the Ya'amūn Byzantine church are of equally high quality as those in contemporaneous churches of the nearby Decapolis cities (El-Najjar et al., 2001, Rose et al., 2007).

\section{Diet and environmental reconstruction by carbon and nitrogen stable isotope}

\section{analysis of bone collagen}

The ratios of the stable isotopes of carbon $\left({ }^{13} \mathrm{C} /{ }^{12} \mathrm{C}\right)$ and nitrogen $\left({ }^{15} \mathrm{~N} /{ }^{14} \mathrm{~N}\right)$ are amongst the most frequently measured in ancient skeletal remains for diet and environmental reconstruction. These ratios are conventionally referred to relative to a standard as $\delta^{13} \mathrm{C}$ and $\delta^{15} \mathrm{~N}$ values, respectively. Due to isotope partitioning, isotopes of the same element are unequally distributed in different types of soils, and in different water bodies, plants and animals (Ehleringer and Rundel, 1989, Hoefs, 2009). As a result, organisms from different ecosystems can have distinct isotopic signatures and, similarly, their isotopic composition may vary according to their trophic level (Kelly, 2000).

Feeding experiments have shown that the stable isotope ratios measured in human and animal bone collagen reflect the isotopic composition of plant and animal foods, and especially of the dietary protein (Ambrose and Norr, 1993, Tieszen and Fagre, 1993, Froehle et al., 2010), consumed over several years of life (Hedges et al., 2007). 
Photosynthesis is the main source of carbon isotopic variation in terrestrial ecosystems. According to their photosynthetic pathway, terrestrial plants fall into two main groups, $C_{3}$ and $C_{4}$ plants. $C_{3}$ plants are characteristic of the temperate environments and include most plants used for human consumption such as wheat, barley, most fruits, legumes and nuts. In contrast, $\mathrm{C}_{4}$ plants are adapted to high light intensity, high temperatures and frequent water shortages. They include many tropical grasses and the cultural crops millet, sorghum, maize and sugar cane (van der Merwe, 1989).

During photosynthesis, $\mathrm{C}_{3}$ plants tend to incorporate less ${ }^{13} \mathrm{C}$ by discriminating more than $\mathrm{C}_{4}$ plants against ${ }^{13} \mathrm{CO}_{2}$. The tissues of $\mathrm{C}_{3}$ plants therefore have lower $\delta^{13} \mathrm{C}$ values than $\mathrm{C}_{4}$ plants. Mean $\delta^{13} \mathrm{C}$ values are $-26 \%$ and $-12.5 \%$ for $C_{3}$ and $C_{4}$ plants, respectively (Smith and Epstein, 1971). These differences in the isotope values of the plants are reflected in the isotopic signature of the consumers, although absolute values are slightly changed by different metabolic pathways (DeNiro and Epstein, 1978 and studies summarised in Ambrose and Norr 1993). The carbon isotope composition of bone collagen therefore provides an indication of the relative contributions of $\mathrm{C}_{3}$ and $\mathrm{C}_{4}$ plants to the diet of herbivores and, in turn, may give indication of their abundance in the environment. For the humans, who in most cases eat an omnivorous diet, $\delta^{13} \mathrm{C}$ values can reflect either direct consumption of plants or the isotopic composition of meat and dairy products derived from $\mathrm{C}_{3}$ - or $\mathrm{C}_{4}$-fed animals (Ambrose, 1993). $\delta^{13} \mathrm{C}$ values are also used to identify consumption of marine resources as marine foods have substantially higher $\delta^{13} \mathrm{C}$ than terrestrial $\mathrm{C}_{3}$ foods (Richards and Hedges, 1999, Schoeninger and DeNiro, 1984). However, within the environmental context of Jordan, it is the variable reliance on $\mathrm{C}_{3}$ and $\mathrm{C}_{4}$ plants that is likely to explain most carbon isotope variation in animals and humans.

Bone collagen $\delta^{15} \mathrm{~N}$ values are mainly used as an indicator of the trophic position of an organism in the foodweb, an attribute which is based on the enrichment of consumer tissues in ${ }^{15} \mathrm{~N}$ with each step up the food chain (DeNiro and Epstein, 1981, Minagawa Wada, 1984, Schoeninger and DeNiro, 1984), breastfeeding mammals being at the top of this sequence (Fuller et al., 2006). 
Although trophic level enrichments are consistently observed in modern foodwebs, estimating the

120 relative contributions of plant and animal protein in omnivorous diets is complicated by a number

121 of factors, not the least uncertainty about the exact mechanisms behind the trophic level effect and how the diet-tissue spacing is affected by various nutritional and metabolic factors (Vanderklift and Ponsard, 2003, Caut et al., 2009). While a full trophic offset in collagen stable isotope studies is commonly estimated as between 3 and 5\%o (Bocherens and Drucker, 2003), higher values in humans have also been suggested (Hedges and Reynard, 2007, O'Connell et al., 2012). It is generally acknowledged that, because most plants are relatively low in protein, their contribution to the diet will be underrepresented in the collagen stable isotope signal; however, another issue that has been raised more recently is the fact that the isotopic composition of plant foods usually needs to be estimated from the bone collagen values of domestic herbivores which may not always give a 130 truthful reflection of the plants used for human consumption (Fraser et al., 2013). Despite these 131 issues, studies have shown that the use of $\delta^{15} \mathrm{~N}$ as a broad indicator of the level of animal protein consumption in humans is overall sound, even though they cannot distinguish between different

133 foods of animal origin such as between meat and dairy products (O'Connell and Hedges, 1999, 134 Petzke et al., 2005).

135 Although bone stable isotope data are primarily a reflection of diet, isotope analysis of faunal, 136 specifically herbivore remains has also been used to indirectly reconstruct environmental 137 conditions, the underlying principle being that herbivore data provide an averaged isotope value for 138 the local vegetation, the isotopic composition of which will vary according to a number of 139 environmental and climatic factors (Hedges et al., 2004, van Klinken et al., 1994). Most obviously, 140 herbivore $\delta^{13} \mathrm{C}$ values may give information about the proportion of $\mathrm{C}_{3}$ versus aridity-adapted $\mathrm{C}_{4}$ 141 plants in an area - although the feeding preferences of individual species must also be taken into 142 account (Ambrose and DeNiro, 1986, Hartman et al., 2013). Variations in temperature or rainfall 143 patterns, among others, also affect the isotopic composition of $\mathrm{C}_{3}$ plants and may therefore be 
traceable in herbivore tissues (Hartman and Danin, 2010, van Klinken et al., 1994). For nitrogen isotope ratios, a marked inverse correlation has been demonstrated between bone collagen $\delta^{15} \mathrm{~N}$ values and rainfall, so that herbivores living in arid environments show elevated $\delta^{15} \mathrm{~N}$ values (Ambrose and DeNiro, 1986, Heaton et al., 1986). While physiological mechanisms have been proposed in explanation (Ambrose, 1991, Sealy et al., 1987), it is now thought most likely that the 'rainfall effect' is due to the ${ }^{15} \mathrm{~N}$-enrichment of plants, through the effects of denitrification and ammonia volatilization in the soil (Hartman, 2011, Heaton, 1987, Murphy and Bowman, 2006,

151 Schwarcz et al., 1999). A linkage has also been found between high $\delta^{15} \mathrm{~N}$ values in cultivated plants and use of manure on fields (Bogaard et al., 2007, Fraser et al., 2011) and should be kept in mind when comparing the $\delta^{15} \mathrm{~N}$ values of humans and their domestic animals.

\section{Materials and Methods}

The excavation of the Ya'amūn tombs led to the identification of Middle Bronze Age, Late Bronze Age, Late Roman and Byzantine burials, with dating achieved through a systematic study of pottery fragments and grave goods, and of the architectural features (Al-Shorman, 2004, Barnes, 2003, Burke and Rose, 2001, El-Najjar and Rose, 2003, El-Najjar et al., 2001, Rose et al., 2007). From the skeletal remains made accessible at the Department of Archaeology and Anthropology of the

161 University of Yarmouk (Irbid, Jordan), it was possible to sample 45 individuals. Of these, 22 date to the Middle-Late Bronze Age, while 23 date to the Late Roman-Byzantine period. A further 23 samples were obtained from the remains of adult domestic ungulates and fishbone recovered from well-dated contexts. The entire assemblage was highly fragmented. In the case of the human remains, this prevented the assessment of age and sex. For the faunal remains, it was usually problematic to distinguish between sheep (Ovis aries) and goats (Capra hircus) on morphological grounds. These are therefore collectively referred to as domestic ovicaprids or as sheep/goats (for 
more information on sampling processing and analysis see Supplementary Information). Isotopic differences between the two species on account of their feeding ecology are not expected in the environmental context of the southern Levant (see Hartman et al., 2013: S1).

\section{Results}

The $\delta^{13} \mathrm{C}$ and $\delta^{15} \mathrm{~N}$ isotope data and quality indicators of the faunal and human bone samples from Ya'amūn are reported in Tables S1 and S2 (see Supplementary Materials), respectively. Fifty (18 faunal and 32 humans samples) out of 68 bone specimens yielded good quality collagen (Ambrose 1990; DeNiro 1985). Descriptive statistics for each of the sample groups are presented in Table 1. The highest variability was found amongst the Bronze Age (MBA and LBA combined) animals, while the Late Antique (LR-Byz) sheep/goats presented the lowest. The $\delta$-values of the domestic herbivores, illustrate a clear difference in the diet of Bronze Age and Late Antique sheep/goats with apparently decreased $\delta^{13} \mathrm{C}$ and $\delta^{15} \mathrm{~N}$ in the later periods (Figure 2). Although the difference is statistically significant for $\delta^{15} \mathrm{~N}$ only (Independent Samples Mann-Whitney test with exact probabilities to account for small sample sizes: $U=11.5, p=0.537$ for $\delta^{13} \mathrm{C} ; \mathrm{U}=1.0, p=0.009$ for $\left.\delta^{15} \mathrm{~N}\right)$, the $\delta^{13} \mathrm{C}$ and $\delta^{15} \mathrm{~N}$ values of the MBA/LBA sheep-goats are clearly correlated $\left(\mathrm{r}^{2}=0.75\right)$.

While the later ovicaprids had a more monotonous diet, the two LR/Byz Bos specimens plot relatively far apart, with a $3.2 \%$ difference in $\delta^{13} \mathrm{C}$ and a $4.3 \%$ difference in $\delta^{15} \mathrm{~N}$ values. In Figure 3, the human values are compared to the terrestrial fauna. No statistically significant differences were found between human isotope values from MBA and LBA (Independent samples MannWhitney test, $U=22.5, p=0.536$ for $\delta^{13} \mathrm{C}$ and $\mathrm{U}=18.0, \mathrm{p}=1.0$ for $\left.\delta^{15} \mathrm{~N}\right)$, and Late Roman and Byzantine Ya'amūn $\left(U=8.5, p=0.667\right.$ for $\delta^{13} \mathrm{C}$ and $U=4.5, p=1.83$ for $\left.\delta^{15} N\right)$. Consequently these were pooled into one Bronze Age and one Late Antique group. The differences between the Bronze Age and Late Antique humans are statistically significant for both carbon and nitrogen 
191 (Independent-sample Mann-Whitney test, $U=49.0, p=0.002$ for $\delta^{13} \mathrm{C}$ and $U=55.5, p=0.005$ for $\left.192 \delta^{15} \mathrm{~N}\right)$.

\section{Discussion}

\subsection{The fauna from Ya'amūn}

196 Overall, the range of $\delta^{13} \mathrm{C}$ values of the domestic ungulates from Ya'amūn indicates that they were 197 grazing in an environment where $C_{3}$ vegetation dominates over $C_{4}$ vegetation. These results are in 198 agreement with the data presented previously by Al-Shorman $(2004,2003)$ and King $(2001)$ on the 199 human diet and are also consistent with the vegetation composition around the site in modern times 200 (Al-Eisawi 1996, Shomer-Ilan et al., 1981, Vogel et al., 1986, Winter, 1981). Nevertheless, the 201 most positive $\delta^{13} \mathrm{C}(-16.6 \%$ for sheep/goat and $-15.6 \%$ for cattle, Table 1$)$ indicate the inclusion of 202 varying and sometimes substantial amounts of $\mathrm{C}_{4}$ plants in the animals' diet. These higher $\delta^{13} \mathrm{C}$ 203 values are correlated with raised $\delta^{15} \mathrm{~N}$ values which are also consistent with grazing in arid regions 204 (Hartman and Danin, 2010, Heaton, 1987, see section 3 above).

205 The differences observed in the sheep/goat data from the Bronze Age and Late Antiquity (Figure 2) 206 are consistent with suggestions that climate in the MBA and LBA in the Southern Levant was dry 207 and similar to present conditions, while sedimentological and palynological evidence as well as 208 speleothem oxygen isotope analyses unequivocally indicate wetter conditions in the Roman and 209 Byzantine periods (Bookman et al., 2004; Enzel et al., 2003; Neumann et al., 2007; Orland et al., 210 2009; Finné et al., 2011; Rambeau and Black 2011). Nevertheless, if climatic conditions in the $211 \mathrm{MBA} / \mathrm{LBA}$ were indeed similar to the present day and even more so if, as has also been suggested, 212 they were slightly wetter (see Rambeau and Black 2011: 99), it is unlikely that the MBA/LBA 213 sheep/goats with elevated carbon and/or nitrogen isotope values (at least half of what is, admittedly, 214 a small sample) could have acquired these by freely foraging in the immediate hinterland of the site. 
215 Ya'amūn itself is situated in the xeric Mediterranean phytogeographic zone which receives modest 216 rainfall (currently $\sim 400 \mathrm{~mm} /$ year) and therefore has little $\mathrm{C}_{4}$ vegetation, which only becomes notable 217 in areas with less than $\sim 350 \mathrm{~mm}$ annual precipitation. The observed $\delta$-values are therefore 218 consistent with animals grazing in much drier environments and these indeed provide the best 219 parallels among published data. According to the large reference data-set compiled by Hartman et 220 al. (2013), the MBA/LBA sheep/goats from Ya'amūn are most consistent with ovicaprids feeding 221 in the desert zone, although similar isotope values have also been produced for goats from a semi222 arid steppe environment (Makarewicz and Tuross, 2012). In any case, the Bronze Age herbivore 223 data from Ya'amūn suggest that sheep/goat were herded away from the site for at least part of the 224 year. The isotope values for the sheep/goat from Ya'amūn are almost identical to another small 225 data-set of MBA sheep from Tell Al-Husn, only a few kilometres to the north (Al-Bashaireh and 226 Al-Muheisen, 2011). Here, elevated isotope values were only observed in three very young 227 individuals and the ${ }^{15} \mathrm{~N}$-enrichment was consequently attributed to a 'suckling effect'; however, the consumption of mother ewes' milk cannot easily explain the relatively large difference in $\delta^{13} \mathrm{C}$ between the young and adult sheep (Balasse et al., 1999), which approaches 2\%o. Instead, the bones 230 of the suckling sheep may record a seasonal shift in the diet of the mothers, during the gestation 231 period and early life of their lambs, to include ${ }^{13} \mathrm{C}$-enriched graze. Transhumance is standard 232 practice amongst the traditional pastoralists in the southern Levant who, usually, spend the months 233 between November and April leading herds to the green pastures that develop in arid and semi-arid 234 areas during the rainfall season. This system has the added advantage of keeping the animals away 235 from agricultural fields during the crop growing season (Levy, 1983, Safrai, 2004, 93). Texts dated 236 to the Middle and Late Bronze periods of Syria-Palestine and Anatolia describe various strategies 237 for managing domestic herbivores (Liverani, 1988, 374, 437), and how, for instance, the sheep 238 owned by the elites spent most of the year away from the city to return only for the shearing season 239 (Snell, 1997, 72, 126). Another scenario is that animals raised at sites in the more arid zones were 
brought to Ya'amūn, which fits with artefactual evidence that the site was part of a network of

241 commercial exchanges connecting north Jordan with the wider eastern Mediterranean (Bourke et

242 al., 2006, Strange, 2008), and would also explain why only part of the MBA/LBA sheep/goat

243 sample exhibit the raised stable isotope values.

244 In contrast, the Late Roman/Byzantine animals were feeding almost entirely, if not exclusively, on

$245 \mathrm{C}_{3}$ plants and their $\delta^{15} \mathrm{~N}$ values are significantly lower than in the earlier animals. Assuming, as

246 Hartman et al. (2013: 4372) argue, that the wetter climatic conditions in Late Antiquity did not

247 significantly shift the boundaries of environmental zones in the region, this suggests that the

248 sheep/goats of this later period were more restricted in their mobility. They would have grazed on

249 unused fields and between the orchards in the surroundings of Ya'amūn where conditions were

250 relatively moist because of wide-ranging irrigation. It is known that vine leaves and trimmings were

251 sometimes used as animal fodder (Horden and Purcell, 2000, 214) and these must have been

252 abundant at Ya'amūn, where vine cultivation was extensive (see above).

253 There are too few cattle data to attempt reconstructing husbandry regimes, but it is nevertheless

254 interesting to observe that the two Late Antique cattle have sharply diverging $\delta^{13} \mathrm{C}$ and $\delta^{15} \mathrm{~N}$ values

255 (Figure 2). While one plots close to the contemporaneous sheep/goats, the other has substantially

256 higher $\delta^{13} \mathrm{C}$ and $\delta^{15} \mathrm{~N}$ values, suggesting that it fed in a much drier environmental zone and/or an

257 area where $\mathrm{C}_{4}$ fodder crops had been adopted (Copley et al., 2004). The animal therefore suggests

258 that livestock was brought to Late Antique Ya'amūn from the outside.

259 Ya'amūn freshwater and marine fish isotope values (Table S1, Figure 4) are comparable with 260 results from archaeological fish from Greece (Vika \& Theodoropoulou 2012). The values for the

261 marine species, in particular, add to a growing corpus of data that show fish from the Mediterranean

262 to be ${ }^{13} \mathrm{C}$-enriched and ${ }^{15} \mathrm{~N}$-depleted compared to animals from the North Atlantic. The observed

263 differences in $\delta^{15} \mathrm{~N}$ between the fish samples can be explained by differences in trophic level 
264 (Froese and Pauly, 2014) and variation in the isotopic composition of aquatic primary producers 265 (Ambrose 1993; France 1995; Fuller 2012b; Katzenberg \& Weber 1999; Schoeninger \& DeNiro 266 1984).Particularly notable is the stark difference in $\delta^{13} \mathrm{C}$ between the two LR/Byz samples of the 267 freshwater genus Tilapia, which exceeds $10 \%$ and indicates that these specimens lived in very 268 different environments. The $\delta^{13} \mathrm{C}$ values for modern Tilapia from Lake Tiberias (Zohary et al., 269 1994), once corrected for the offset between muscle and bone collagen as well as lipid content, are 270 very close to the relatively ${ }^{13} \mathrm{C}$-depleted value observed for YMNTfb100. An origin from the river 271 Jordan or the Lake itself therefore appears plausible. The same may then be true for the specimen of 272 Claridae (catfish, YMNTfb102), as variation between the two could mostly be accounted for by 273 differences in trophic level. Tilapia are also known to inhabit coastal rivers, including those of the 274 southern Levant (Van Neer et al., 2000) and a significant input from marine biomass could explain 275 why specimen YMNTfb101 is substantially ${ }^{13} \mathrm{C}$-enriched over YMNTfb100. Nevertheless, Vika 276 and Theodoropoulou (2012) have observed similar carbon isotope values for freshwater fish from 277 Greece. Tilapia are bottom feeders and it is possible that their foodwebs are ${ }^{13} \mathrm{C}$-enriched by poor 278 availability of $\mathrm{CO}_{2}$ in warm and stagnant waters (France, 1995, Hecky and Hesslein, 1995), perhaps 279 combined with a hard water effect in a region where marine carbonate is the dominant geological 280 substrate (Day, 1996). Further isotope studies on freshwater fish from the Levant will be necessary 281 to test this hypothesis.

\subsection{The inhabitants of Ya'amūn}

283 The isotope values show that terrestrial $\mathrm{C}_{3}$-derived resources dominated human diet at Ya'amūn.

284 The isotopic differences between Bronze Age and Late Antique humans mirror those between the 285 sheep/goats from both periods and suggest that much of what first appears as dietary variation can 286 instead be explained by a baseline-shift in the isotopic composition of available food sources

287 (Figure 3). Because of the impact of water availability on carbon isotope discrimination of $\mathrm{C}_{3}$ plants 
during photosynthesis (Farquhar et al., 1989), it is likely that the plant foods available at Ya'amūn in the Bronze Age were also ${ }^{13} \mathrm{C}$-enriched over those cultivated under the wetter conditions of the Late Roman/Byzantine period. It should be noted that the same cannot necessarily be assumed for

291 plant $\delta^{15} \mathrm{~N}$ values as these are determined by numerous complex mechanisms (Evans, 2001, 292 Högberg, 1997). Cultivated fields especially may be subject to additional measures such as the 293 application of animal fertilizers (Fraser et al., 2011). Despite significant differences in the isotopic composition of the bone collagen, human diet between the two time periods may therefore not have varied greatly in terms of the actual staple foods consumed and their relative proportions.

In this context, the relatively large difference in the average $\delta^{15} \mathrm{~N}$ human-herbivore offset ( $\Delta^{15} \mathrm{~N}_{\text {human-herbivore }}$, which is 3.5\% in the Late Antique but only $0.3 \%$ in the Bronze Age sample, requires some discussion. If herbivore $\delta^{15} \mathrm{~N}$ were used to estimate the nitrogen isotope composition of plants consumed by humans and the spacing between humans and animals was therefore taken as an indicator for the relative contributions of plant and animal protein to the human diet (Hedges and Reynard, 2007), these data would suggest that Bronze Age diet was almost entirely based on plant foods, while humans in Late Antiquity habitually consumed large amounts of animal protein ( $70 \%$ of the dietary protein according to Hedges and Reynard's (2007) 'standard model', even if a generous trophic level offset of $+5 \%$ is used). Either of these extreme scenarios seems unlikely in light of evidence for diet in these periods available from other sources (Grigson, 1998, 256; Safrai, 2004, 96).

The human isotope data from MBA/LBA Ya'amūn are almost identical to those obtained from EBA/MBA Tell Al-Husn (mean $\delta^{13} \mathrm{C}$ and $\delta^{15} \mathrm{~N}$ values \pm 1 s.d.: $-18.5 \pm 0.4 \%$ ond $8.7 \pm 0.8, \mathrm{n}=10$ ), and suggest that the subsistence regime reflected was typical for the wider region (Al-Bashaireh and Al-

310 Muheisen, 2011). It cannot be denied that staple foods derived from $\mathrm{C}_{3}$ cereals such as wheat and 311 barley made up the bulk of the diet at this time (Zohary and Hopf, 2000; see Snell, 1997; for Jordan 
see Bourke et al., 2003; McNicoll et al., 1992; Tubb 1988; Tubb et al., 1997). Nevertheless, the

313 faunal assemblage from BA Ya'amūn itself as well as nearby sites such as Pella (Bourke et al.,

314 1994, Bourke et al., 1998) demonstrate that sheep and goat husbandry was well-established in the

315 region during the Bronze Age. While the emphasis may have been on wool production processing

316 of surplus dairy and the consumption of meat from animals that had outlived their usefulness would

317 have been an integrated part of this economy (Grigson, 1998, 256). If it is therefore unlikely that the

318 human diet was almost entirely plant-based, the relatively low $\delta^{15} \mathrm{~N}$ values in the BA humans

319 compared to the animal data need additional explanation. Pulses, especially lentils, were important

320 protein-rich foods and a means of crop and diet diversification in the entire Mediterranean area

321 since the beginning of agriculture (Grigson, 1998, Horden and Purcell, 2000, 203). Like other

322 leguminous plants, they are able to fix nitrogen directly from the atmosphere and, as a result, are

323 habitually ${ }^{15} \mathrm{~N}$-depleted compared to other crops. Their regular inclusion in the diet would therefore

324 have the effect of lowering the $\delta^{15} \mathrm{~N}$ of human consumers, potentially masking the consumption of

325 animal products (Fraser et al., 2013).

326 If the human-herbivore $\delta^{15} \mathrm{~N}$ offset therefore likely underrepresents the role of animal products in 327 the Bronze Age diet at least to an extent, the opposite may be true for the Late Roman/Byzantine 328 sample. It is well-established that cereals, in the form of wheat or barley bread, contributed the 329 majority of the daily caloric intake in Roman-period Palestine, while the degree to which animal 330 products were part of everyday diet varied according to wealth and, particularly for fish, to the 331 distance from the place of production (Broshi, 1986, Dar, 1995, Garnsey, 1999:16, Safrai 2004, 332 Wilkins and Hill, 2006). Ya'amūn in Late Antiquity was the site of intensive agriculture, and 333 manuring was widely practiced in Romano-Byzantine Palestine (Almagro, 2007). The herbivore $334 \delta^{15} \mathrm{~N}$ may therefore well underestimate the nitrogen isotope composition of the cultivated plants (see 335 Fraser et al., 2013). Written sources from the region also describe a system of crop rotation where 336 wheat fields were periodically turned over to leguminous plants and used as animal pasture (Safrai, 
2004, 98). Alternatively, dietary diversification may be responsible for the human-herbivore

spacing. In the Roman period, domestic fowl and chicken especially gained economic importance in the Southern Levant and it has been suggested that egg consumption was considerable (Safrai 2004: 101-102). Quantitative data from Ya'amūn do not exist, but at nearby Pella, reliance on poultry, mostly chicken, increases sharply during the Byzantine period (McNicoll et al., 1982, 110). The isotopic composition of eggs depends on the diet of the chicken (Hobson, 1995); however, because 343 of their omnivorous feeding ecology, these can be significantly ${ }^{15} \mathrm{~N}$-enriched over herbivores 344 (Müldner and Richards, 2007).

345 There are numerous sources emphasizing the importance of fish and fish products in Roman and Byzantine Palestine (Garnsey, 1999, Lev-Tov, 2003, Marzano, 2013, Purcell, 1995, Van Neer and Parker, 2008). Based on the fishbone isotope data assembled here, there is little conclusive evidence that fish made any measurable contribution to Roman-Byzantine diet at Ya'amūn. Lack of isotopic separation between freshwater fish and terrestrial animals makes it very difficult to convincingly demonstrate the consumption of freshwater fish, and although the $\delta^{15} \mathrm{~N}$ values of the Late Antique humans could theoretically be explained by small-scale consumption of higher trophic level marine fish (such as the specimen of Sciaenidae, YMNfb88), Ya'amūn's inland location and the fact that YMNfb88 (which actually dates to the MBA) plots at the top end of $\delta^{15} \mathrm{~N}$ values measured for

354 Mediterranean fish to date (and is therefore not necessarily representative of any marine fish that 355 reached the site), make significant consumption of marine protein at the site very unlikely .

356 The isotope data from Ya'amūn are very similar to those from other Late Antique sites in the 357 Levant (Al-Bashaireh and Al-Muheisen, 2011, Fuller et al., 2012a, Gregoricka and Sheridan, 358 2013), suggesting again a similar subsistence base for the wider region. Unlike some other bone 359 collagen data-sets (Bourbou et al., 2011, Iacumin et al., 1998, Thompson et al., 2008), the sample 360 from Ya'amūn does not have any statistical outliers that would suggest that individuals moved from 361 ecologically different regions, although the sample size is too small for any far-reaching 
conclusions and carbon and nitrogen isotopes are not well suited to identify migrants in a population in any case.

\section{Conclusions}

Despite the small sample sizes which are, unfortunately, a common limitation of bone isotope investigations in arid and semi-arid regions, this study has established a number of clear trends. Of particular importance are differences in animal husbandry between the Middle and Late Bronze Age and Late Antiquity, which involved Bronze Age sheep/goats spending at least part of the year in arid or semi-arid regions, while Romano-Byzantine animals evidently stayed in the same phytogeographic zone. The reason behind this significant economic change may be the greater abundance of suitable fodder in the slightly wetter climate of Late Antiquity or else the need to keep

373 the human workforce on-site to concentrate on other agricultural tasks, including the work-intensive viticulture (Horden and Purcell, 2000, 215). The cattle data from this period nevertheless show that the site was still connected to the drier regions to the East and South, possibly reflecting the move to expand agricultural production to the more marginal areas in the Byzantine period (Watson, 2008). As expected based on the results of previous studies, the human diet in both periods was

378 based almost exclusively on $\mathrm{C}_{3}$-based resources. While most isotopic differences between the 379 human groups can be explained in terms of a baseline shift due to climatic change between the two 380 periods, the Middle and Late Bronze Age inhabitants of Ya'amūn may have consumed a greater 381 proportion of leguminous plants, while the diet in Late Antiquity could have included a wider range 382 of foods. Alternatively, their isotopic data may reflect the documented agricultural intensification in 383 this period. Neither freshwater nor marine fish seem to have contributed significantly to the food 384 intake of the sampled individuals. Overall, this study illustrates the need to analyse coeval faunal remains for human palaeodietary studies and confirms the great value of carbon and nitrogen stable 
isotope analysis of herbivores for reconstructing environmental conditions in relation to changes in geographical location and climate.

\section{Acknowledgements}

This study, part of MS's PhD, was financed by Leverhulme Trust as part of the project "Water Life and Civilisation". Thanks go to Prof. Steven J. Mithen, University of Reading, for help and advice during PhD supervision. We are grateful to Prof. Mahmoud El-Najjar †, Dr Abdulla Al-Shorman,

Dr Mohammad Al-Rousan and Dr Ammar Al-Obiedat of the Institute of Archaeology and Anthropology of Yarmouk University, Irbid, Jordan, to Prof Jerome Rose of the University of Arkansas, USA, for access to the skeletal material and for providing assistance and advice during sampling. We gratefully acknowledge the Department of Antiquities of Jordan as well as staff of support during the 2006 fieldwork. Thanks go to Prof. Wim Van Neer, University of Leuven, for the identification of the fish vertebrae, Sarah Lambert-Gates (Reading) and Carlos H. Caracciolo (INGV, Bologna) for production of maps, and two anonymous reviewers for their constructive and 400 helpful comments.

\section{References}

Adams, R. B. (ed.) 2008. Jordan, An Archaeological Reader, London: Equinox.

Al-Bashaireh, K.and Al-Muheisen, Z. 2011. Subsistence strategies and palaeodiet of Tell al-Husn, northern Jordan: nitrogen and carbon stable isotope evidence and radiocarbon dates. Journal of Archaeological Science, 38, 2606-2612.

Al-Eisawi, D. M. 1985. Vegetation in Jordan. In: Hadidi, A. (ed.) Studies in the History and Archaeology of Jordan 2. Amman: Department of Antiquities.

Al-Eisawi, D. M. 1996. Vegetation of Jordan, Cairo, UNESCO: Regional Office for Science and Technology for the Arab States. 
Al-Shorman, A. 2003. Byzantine palaeodiet and social status at Sa'ad and Yasieleh in Northern Jordan. Athena Review, 3, 60-63.

Al-Shorman, A. 2004. Stable carbon isotope analysis of human tooth enamel from the Bronze Age cemetery of Ya'amoun in Northern Jordan. Journal of Archaeological Science, 31, 1693 1698.

Almagro, A. 2007. Soil Improvement and Agricultural Pesticides in Antiquity: Examples from Archaeological Research in Israel. In: Conan, M. (ed.) Middle East Garden Traditions: Unity and Diversity. Washington D.C.: Dumbarton Oaks.

Ambrose, S. H. 1990. Preparation and characterisation of bone and tooth collagen for isotopic analysis. Journal of Archaeological Science, 17, 431-451.

Ambrose, S. H. 1991. Effects of diet, climate and physiology on nitrogen isotopes abundances in terrestrial foodwebs. Journal of Archaeological Science, 18, 293-317.

Ambrose, S. H. 1993. Isotopic analysis of palaeodiets: methodological and interpretative considerations. In: Sandford, M. K. (ed.) Investigation of Ancient Human Tissue: Chemical Analysis in Anthropology. Langthorne: Gordon and Breach, 59-130.

Ambrose, S. H.and DeNiro, M. J. 1986. The isotopic ecology of East African mammals. Oecologia, 69, 395-406.

Ambrose, S. H.and Norr, L. 1993. Experimental evidence for the relationship of the carbon isotope ratios of whole diet and dietery protein to those of bone collagen and carbonate. In: Lambert, J. B. \& Grupe, G. (eds.) Prehistoric Human Bone. Archaeology at the Molecular Level. Berlin: Springer-Verlag, 1-37.

Balasse, M., Bocherens, H.and Mariotti, A. 1999. Intra-bone variability of collagen and apatite composition used as evidence of a change of diet. Journal of Archaeological Science, 26, 593-598.

Barnes, J. S. 2003. Tell Ya 'amūn: Mortuary, Biological and Cultural Characteristics. Unpublished MA dissertation. Master of Arts MA Dissertation, University of Arkansas.

Bocherens, H.and Drucker, D. 2003. Trophic level isotopic enrichment of carbon and nitrogen in bone collagen: case studies from recent and ancient terrestrial ecosystems. International Journal of Osteoarchaeology, 13, 46-53.

Bogaard, A., Heaton, T. H. E., Poulton, P.and Merbach, I. 2007. The impact of manuring on nitrogen isotope ratios in cereals: archaeological implications for reconstruction of diet and crop management practices. Journal of Archaeological Science, 34, 335-343.

Bookman, R., Y. Enzel, a. Agnon, and M. Stein. 2004. 'Late Holocene Lake Levels of the Dead Sea.' Bulletin of the Geological Society of America 116, 555-571.

Bourbou, C., Fuller, B. T., Garvie-Lok, S. J.and Richards, M. P. 2011. Reconstructing the diets of Greek Byzantine populations (6th-15th centuries AD) using carbon and nitrogen stable isotope ratios. American Journal of Physical Anthropology, 146, 569-581.

Bourke, S., Sparks, R.and Schroder, M. 2006. Pella in the Middle Bronze Age. In: Fischer, P. M. (ed.) The Chronology of the Jordan Valley During the Middle and Late Bronze Ages : Pella, Tell Abu Al-Kharaz, and Tell Deir ${ }^{c}$ Alla. Wien: Verlag der Österreichischen Akademie der Wissenschaften, 9-58.

Bourke, S., Sparks, R., Sowada, K. N.and Mairs, L. 1994. Preliminary report of the University of Sydney's fourteenth season of excavations at Pella (Tabaqat Fahl) in 1992. Annual of the Department of Antiquities of Jordan, 38, 81-126. 
Bourke, S., Sparks, R., Sowada, K. N., McLaren, P. B.and Mairs, L. 1998. Preliminary report on the University of Sydney's sixteenth and seventeenth seasons of excavations at Pella (Tabaqat Fahl) in 1994/95. Annual of the Department of Antiquities of Jordan, 42, 179-211.

Bourke, S. J., Sparks, R. T., McLaren, B., Sowada, K., Mairs, L. D., Meadows, J., Hikade, T.and Reade, W. 2003. Preliminary reports on the University of Sydney's eighteenth and nineteenth seasons of excavations at Pella (Tabaqat Fahl) in 1996/97. Annual of the Department of Antiquities of Jordan, 47, 335-388.

Broshi, M. 1986. The diet of Palestine in the Roman Period - Introductory notes. Israel Museum Journal, 46, 41-56.

Burke, D. L.and Rose, J. C. 2001. Les morts de Ya'amūn. Le Monde de la Bible, 133, 56.

Cameron, A. 1993. The Mediterranean World in Late Antiquity, London, Routledge.

Caut, S., Angulo, E.and Courchamp, F. 2009. Variation in discrimination factors (Delta N-15 and Delta C-13): the effect of diet isotopic values and applications for diet reconstruction. Journal of Applied Ecology, 46, 443-453.

Copley, M. S., Jim, S., Jones, V., Rose, P., Clapham, A., Edwards, D. N., Horton, M., RowleyConwy, P.and Evershed, R. P. 2004. Short- and long-term foraging and foddering strategies of domesticated animals from Qasr Ibrim, Egypt. Journal of Archaeological Science, 31, 1273-1286.

Cordova, C. E. 2007. Millennial Landscape Change in Jordan, Tucson, The University of Arizona Press.

Dar, S. 1995. Food and archaeology in Romano-Byzantine Palestine. In: Wilkins, J., Harvey, D. \& Dobson, M. (eds.) Food in Antiquity. Exeter: University of Exeter Press.

Day, S. P. 1996. Dogs, Deer and Diet at Star Carr: a Reconsideration of C-isotope Evidence from Early Mesolithic Dog Remains from the Vale of Pickering, Yorkshire, England. Journal of Archaeological Science, 23, 783-787.

DeNiro, M. J. 1985. Postmortem preservation and alteration of in vivo bone collagen isotope ratios in relation to palaeodietary reconstruction. Nature, 317, 806-809.

DeNiro, M. J.and Epstein, S. 1978. Influence of diet on the distribution of carbon isotopes in animals. Geochimica et Cosmochimica Acta, 42, 495-506.

DeNiro, M. J.and Epstein, S. 1981. Influence of diet on the distribution of nitrogen isotopes in animal. Geochimica et Cosmochimica Acta, 45, 341-351.

Ehleringer, J. R.and Rundel, P. W. 1989. Stable isotopes: history, units and instrumentation. In: Rundel, P. W., Ehleringer, J. R. \& Nagy, K. A. (eds.) Stable Isotopes in Ecological Research. New York: Springer-Verlag, pp.1-15.

El-Najjar, M.and Rose, J. C. 2003. Preliminary report of the 2003 field season at Ya'mun by the joint Yarmouk University/University of Arkansas Project. Annual of the Department of Antiquities of Jordan, 47, 491-492.

El-Najjar, M., Rose, J. C., Atallah, N., Turshan, N., Khasawneh, N.and Burke, D. L. 2001. First season of excavation at Ya'mun (1999). Annual of the Department of Antiquities of Jordan, 45, 413-417.

Enzel, Yehouda, Revital Bookman, David Sharon, Haim Gvirtzman, Uri Dayan, Baruch Ziv, and Mordechai Stein. 2003. 'Late Holocene Climates of the Near East Deduced from Dead Sea Level Variations and Modern Regional Winter Rainfall.' Quaternary Research, 60, 263-73. 
Evans, D. R. 2001. Physiological mechanisms influencing plant nitrogen isotope composition. Trends in Plant Science, 6, 121-126.

Farquhar, G. D., Ehleringer, J. R.and Hubick, K. T. 1989. Carbon isotope discrimination and photosynthesis. Annual Review of Plant Physiology: Plant Molecular Biology, 40.

Finné, M., Holmgren, K., Sundqvist, H. S., Weiberg, E.and Lindblom, M. 2011. Climate in the eastern Mediterranean, and adjacent regions, during the past 6000 years - A review. Journal of Archaeological Science, 38, 3153-3173.

France, R. 1995. Differentiation between littoral and pelagic food webs in lakes using stable carbon isotopes. Limnology and Oceanography, 40, 1310-1313.

Fraser, R. A., Bogaard, A., Heaton, T., Charles, M., Jones, G., Christensen, B. T., Halstead, P., Merbach, I., Poulton, P. R., Sparkes, D.and Styring, A. K. 2011. Manuring and stable nitrogen isotope ratios in cereals and pulses: towards a new archaeobotanical approach to the inference of land use and dietary practices. Journal of Archaeological Science, 38, 27902804.

Fraser, R. A., Bogaard, A., Schäfer, M., Arbogast, R.and Heaton, T. H. E. 2013. Integrating botanical, faunal and human stable carbon and nitrogen isotope values to reconstruct land use and palaeodiet at LBK Vaihingen an der Enz, Baden-Württemberg. World Archaeology, 45, 492-517.

Freeman, P. 2008. The Roman Period. In: Adams, R. B. (ed.) Jordan. An Archaeological Reader. London: Equinox, 413-441.

Froehle, A. W., Kellner, C. M.and Schoeninger, M. J. 2010. Effect of diet and protein source on carbon stable isotope ratios in collagen: follow up to Warinner and Tuross (2009). Journal of Archaeological Science, 37, 2662.

Froese, R.and Pauly, D. 2014. Fish Base. [Online]. Available: http://www.fishbase.org [Accessed 20/05/2014].

Fuller, B. T., De Cupere, B., Marinova, E., Van Neer, W., Waelkens, M.and Richards, M. P. 2012a. Isotopic reconstruction of human diet and animal husbandry practices during the ClassicalHellenistic, imperial, and Byzantine periods at Sagalassos, Turkey. American Journal of Physical Anthropology, 149, 157-171.

Fuller, B. T., Müldner, G., Van Neer, W., Ervynck, A.and Richards, M. P. 2012b. Carbon and nitrogen stable isotope ratio analysis of freshwater, brackish and marine fish from Belgian archaeological sites (1st and 2nd millennium AD). Journal of Analytical Atomic Spectrometry, 27, 807-820.

Fuller, B. T., Fuller, J. L., Harris, D. A.and Hedges, R. E. M. 2006. Detection of breastfeeding and weaning in modern human infants with carbon and nitrogen stable isotope ratios. American Journal of Physical Anthropology, 129, 279-293.

Garcia-Guixé, E., Subirà, M. E., Marlasca, R.and Richards, M. P. 2010. $\delta^{13} \mathrm{C}$ and $\delta^{15} \mathrm{~N}$ in ancient and recent fish bones from the Mediterranean Sea. Journal of Nordic Archaeological Science, 17, 83-92.

Garnsey, P. 1999. Food and society in classical antiquity, Cambridge, Cambridge University Press. Gregoricka, L. A.and Sheridan, S. G. 2013. Ascetic or affluent? Byzantine diet at the monastic community of St. Stephen's, Jerusalem from stable carbon and nitrogen isotopes. Journal of Anthropological Archaeology, 32, 63-73. 
Grigson, C. 1998. Plough and pasture in the early economy of the Southern Levant. In: Levy, T. E. (ed.) The Archaeology of Society in the Holy Land. London: Continuum, 245-268.

Hartman, G. 2011. Are elevated $\delta^{15} \mathrm{~N}$ values in herbivores in hot and arid environments caused by diet or animal physiology? Functional Ecology, 25, 122-131.

Hartman, G., Bar-Oz, G., Bouchnick, R.and Reich, R. 2013. The pilgrimage economy of Early Roman Jerusalem (1st century BCE-70 CE) reconstructed from the $\delta^{15} \mathrm{~N}$ and $\delta^{13} \mathrm{C}$ values of goat and sheep remains. Journal of Archaeological Science, 40, 4369-4376.

Hartman, G.and Danin, A. 2010. Isotopic values of plants in relation to water availability in the Eastern Mediterranean region. Oecologia, 162, 837-852.

Heaton, T. H. E. 1987. The ${ }^{15} \mathrm{~N} /{ }^{14} \mathrm{~N}$ ratios of plants in South Africa and Namibia: relationship to climate and coastal/saline environments. Oecologia, 74, 236-246.

Heaton, T. H. E., Vogel, J. C., la Chevallerie, G. v.and Collet, G. 1986. Climatic influence on the isotopic composition of bone nitrogen. Nature, 322, 822-823.

Hecky, R. E.and Hesslein, R. H. 1995. Contribution of benthic algae to lake food webs as revealed by stable isotope analysis. Journal of the North American Benthological Society, 14, 631653.

Hedges, R. E. M., Clement, J. G., Thomas, C. D. L.and O'Connell, T. C. 2007. Collagen turnover in the adult femoral mid-shaft: modeled from anthropogenic radiocarbon tracer measurements. American Journal of Physical Anthropology, 133, 808-816.

Hedges, R. E. M.and Reynard, L. M. 2007. Nitrogen isotopes and the trophic level of humans in archaeology. Journal of Archaeological Science, 34, 1240-1251.

Hedges, R. E. M., Stevens, R. E.and Richards, M. 2004. Bone as a stable isotope archive for local climatic information. Quaternary Science Reviews, 23, 959-965.

Hobson, K. A. 1995. Reconstructing Avian Diets Using Stable-Carbon And Nitrogen Isotope Analysis Of Egg Components - Patterns Of Isotopic Fractionation And Turnover. Condor, 97, 752-762.

Hoefs, J. 2009. Stable Isotope Geochemistry, Berlin et al., Springer.

Högberg, P. 1997. Tansley Review No. $95 .{ }^{15} \mathrm{~N}$ natural abundance in soil-plant systems. New Phytologist, 137, 179-203.

Horden, P.and Purcell, N. 2000. The Corrupting Sea: a Study of Mediterranean History, Oxford, Blackwell.

Iacumin, P., Bocherens, H., Chaix, L.and Marioth, A. 1998. Stable carbon and nitrogen isotopes as dietary indicators of ancient Nubian populations (Northern Sudan). Journal of Archaeological Science, 25, 293-301.

Katzenberg, M. A.and Weber, A. 1999. Stable isotope ecology and palaeodiet in the Lake Baikal region of Siberia. Journal of Archaeological Science, 26, 651-659.

Kelly, J. F. 2000. Stable isotopes of carbon and nitrogen in the study of avian and mammalian trophic ecology. Canadian Journal of Zoology, 78, 1-27.

Kennedy, D. 2007. Gerasa and the Decapolis. A "Virtual Island" in Northwest Jordan, London, Duckworth.

King, M. 2001. Analysis of diet in Byzantine Jordan: isotopic evidence in human dentine (Contribution to the Bioarchaeology of the Levant). Unpublished MA dissertation. Master of Arts MA dissertation, University of Arkansas. 
Levy, T. E. 1983. The emergence of specialized pastoralism in the southern Levant. World Archaeology, 15, 15-36.

Liverani, M. 1988. Antico Oriente, Bari, Editori Laterza.

Lösch, S., Grupe, G.and Peters, J. 2006. Stable isotopes analysis and dietary adaptations in humans and animals at Pre-Pottery Neolithic Nevalı Çori, Southeast Anatolia. American Journal of Physical Anthropology, 131, 181-193.

Makarewicz, C. 2013. More than meat: diversity in caprine harvesting strategies and the emergence of complex production systems during the Late Pre-Pottery Neolithic B. Levant, 45, 236261.

Makarewicz, C.and Tuross, N. 2012. Finding fodder and tracking transumance: isotopic detection of goat domestication processes in the Near East. Current Anthropology, 53, 495-505.

Marzano, A. 2013. Harvesting the Sea: The Exploitation of Marine Resources in the Roman Mediterranean, Oxford, Oxford University Press.

McNicoll, A., Smith, R. H.and Hennessy, B. 1982. Pella in Jordan 1, An interim report on the joint University of Sydney and The College of Wooster excavations at Pella 1979-1981, Canberra, Australian National Gallery.

McNicoll, A. W., Edwards, P. C., Hanbury-Tenison, J., Hennessy, J. B., Potts, T. F., Smith, R. H., Walmsley, A.and Watson, P. (eds.) 1992. Pella In Jordan 2. The second interim report on the joint University of Sydney and The College of Wooster excavations at Pella 1982-1985, Sydney: Mediterranean Archaeology.

Minagawa, M.and Wada, E. 1984. Stepwise enrichment of ${ }^{15} \mathrm{~N}$ along food chains: further evidence and the relation between $\square^{15} \mathrm{~N}$ and animal age. Geochimica et Cosmochimica Acta, 48, 1135-1140.

Müldner, G.and Richards, M. P. 2007. Diet and diversity at Later Medieval Fishergate: the isotopic evidence. American Journal of Physical Anthropology, 134, 162-174.

Murphy, B. P.and Bowman, D. M. J. S. 2006. Kangaroo metabolism does not cause the relationship between bone collagen $\delta^{15} \mathrm{~N}$ and water availability. Functional Ecology, 20, 1062-1069.

Neumann, Frank Harald, Elisa J. Kagan, Markus J. Schwab, and Mordechai Stein. 2007. 'Palynology, Sedimentology and Palaeoecology of the Late Holocene Dead Sea.' Quaternary Science Reviews 26, 1476-98.

O'Connell, T. C.and Hedges, R. E. M. 1999. Investigation into the effect of diet on modern human hair isotopic values. American Journal of Physical Anthropology, 108, 409-425.

O'Connell, T. C., Kneale, C. J., Tasevska, N.and Khunle, G. G. C. 2012. The diet-body offset in human nitrogen isotopic values: A controlled dietary study. American Journal of Physical Anthropology, 149, 426-434.

Orland, Ian J., Miryam Bar-Matthews, Noriko T. Kita, Avner Ayalon, Alan Matthews, and John W. Valley. 2009. 'Climate Deterioration in the Eastern Mediterranean as Revealed by Ion Microprobe Analysis of a Speleothem That Grew from 2.2 to 0.9 Ka in Soreq Cave, Israel.' Quaternary Research 71, 27-35.

Palmer, C. 2013. Biogeography. In: Ababsa, M. (Ed.), Atlas of Jordan: History, Territories and Society. Presses de l'Ifpo: Beyrouth, Retrieved from http://books.openedition.org/ifpo/4871.

Parker, T. S. 1999. An Empire's new Holy Land: the Byzantine Period. Near Eastern Archaeology, 62, 134-180. 
Pearson, J. A., Buitenhuis, H., Hedges, R. E. M., Martin, L., Russel, N.and Twiss, K. C. 2007. New light on early caprine herding strategies from isotope analysis: a case study from Neolithic Anatolia. Journal of Archaeological Science, 34, 2170-2179.

Pearson, J. A., Grove, M., Özbek, M.and Hongo, H. 2013. Food and social complexity at Çayönü Tepesi, southeastern Anatolia: stable isotope evidence of differentiation in diet according to burial practice and sex in the early Neolithic Journal of Anthropological Archaeology, 32, 180-189.

Petzke, K. J., Boeing, H.and Metges, C. C. 2005. Choice of dietary protein of vegetarians and omnivores is reflected in their hair protein ${ }^{13} \mathrm{C}$ and ${ }^{15} \mathrm{~N}$ abundance. Rapid Communications in Mass Spectrometry, 19, 1392-1400.

Purcell, N. 1995. Eating fish: the paradoxes of seafood. In: Wilkins, J., Harvey, D. \& Dobson, M. (eds.) Food in Antiquity. Exeter: University of Exeter Press.

Rambeau, C.and Black, S. 2011. Palaeoenvironments of the Southern Levant 5,000 BP to present: linking geological and archaeological records. In: Mithen, S. \& Black, E. (eds.) Water, Life and Civilisation. Climate, Environment and Society in the Jordan Valley. Cambridge: Cambridge University Press.

Renfro, B.and Cooper, H. K. 2000. Ya'amūn in Egan, V., Bikai P.M., Zamora, K. (eds) Archaeology in Jordan. American Journal of Archaeology, 104, 581.

Richards, M. P.and Hedges, R. E. M. 1999. Stable isotope evidence for similarities in the types of marine foods used by Late Mesolithic humans at sites along the Atlantic coast of Europe. Journal of Archaeological Science, 26, 717-722.

Richards, M. P., Pearson, J. A., Molleson, T. I., Russell, N.and L., M. 2003. Stable isotope evidence of diet at Neolithic Çatalhöyük, Turkey. Journal of Archaeological Science, 30, 67-76.

Rose, J. C. 2001. Tell Ya'amūn 2001 Excavations. [Online]. University of Arkansas. Available: http://cavern.uark.edu/ jcrose/yaamun1/ [Accessed 21/05/2014].

Rose, J. C. 2002. Ya 'amūn 2002 Report [Online]. University of Arkansas. Available: http://cavern.uark.edu/ jcrose/yaamun02/yaamun2.html [Accessed 21/05/2014].

Rose, J. C. 2005. Tell Ya 'amūn: The 2005 Season [Online]. University of Arkansas. Available: http://cavern.uark.edu/ jorose/fieldseason2005/ [Accessed 21/05/2014].

Rose, J. C., El-Najjar, M.and Burke, D. L. 2007. Trade and the acquisition of wealth in rural Late Antique North Jordan. In: Harahsheh, R., Fakhoury, Q., Taher, H. \& Khouri, S. (eds.) Studies in the History and Archaeology of Jordan. Amman: Department of Antiquities of Jordan, 61-70.

Rose, J. C., El-Najjar, M. Y., Hunton, C. I.and Rolf, K. 2003. Tell Ya'amūn in Savage, S.H., Zamora, K.A, Keller, D.L. (eds) Archaeology in Jordan. American Journal of Archaeology, 107, 457-458.

Rosen, A. M. 2007. Civilizing Climate. Social Responses to Climate Change in the Ancient Near East, Lanham, MD, Altamira Press.

Safrai, Z. 2004. The Economy of Roman Palestine, London, Taylor and Francis.

Schoeninger, M. J.and DeNiro, M. J. 1984. Nitrogen and carbon isotopic composition of bone collagen from marine and terrestrial animals. Geochimica et Cosmochimica Acta, 48, 625639.

Schwarcz, H. P., Dupras, T. L.and Fairgrieve, S. I. 1999. ${ }^{15} \mathrm{~N}$ enrichment in the Sahara: in search of a global relationship. Journal of Archaeological Science, 26, 629-636. 
Sealy, J. C., van der Merwe, N., Lee Thorp, J. A.and Lanham, J. L. 1987. Nitrogen isotopic ecology in southern Africa: implications for environmental and dietary tracing. Geochimica et Cosmochimica Acta, 51, 2707-2717.

Shomer-Ilan, A., Nissenbaum, A.and Waisel, Y. 1981. Photosynthetic pathways and the ecological distribution of the Chenopodiaceae in Israel. Oecologia, 48, 244-248.

Smith, B. N.and Epstein, S. 1971. Two categories of ${ }^{13} \mathrm{C} /{ }^{12} \mathrm{C}$ ratios for higher plants. Plant Physiology, 47, 380-384.

Snell, D. C. 1997. Life in the Ancient Near East, New Haven and London, Yale University Press.

Strange, J. 2008. The Late Bronze Age. In: Adams, R. B. (ed.) Jordan. An Archaeological Reader. London: Equinox, 281-310.

Thompson, A. H., Chaix, L.and Richards, M. P. 2008. Stable isotopes and diet in Ancient Kerma, Upper Nubia (Sudan). Journal of Archaeological Science, 35, 376-387.

Thompson, A. H., Richards, M. P., Shortland, A.and Zakrzewski, S. R. 2005. Isotopic palaeodiet studies of Ancient Egyptian fauna and humans. Journal of Archaeological Science, 32, 451 463.

Tieszen, L. L.and Fagre, T. 1993. Effect of diet quality and composition on the isotopic composition of respiratory $\mathrm{CO}_{2}$, bone collagen, bioapatite and soft tissues. In: Lambert, J. B. \& Grupe, G. (eds.) Prehistoric Human Bone, Archaeology at the Molecular Level. Berlin: Springer, 121-155.

Tubb, J. N. 1988. Tell es-Sa idiyeh: preliminary report on the first three seasons of renewed excavations. Levant, 20, 23-88.

Tubb, J. N., Dorrell, P. G.and Cobbing, F. J. 1997. Interim report of the ninth season (1996) of excavations at Tell es-Sa'idiyeh, Jordan. Palestine Exploration Quarterly, 129, 54-77.

van der Merwe, N. J. 1989. Natural variations in ${ }^{13} \mathrm{C}$ concentration and its effect on environmental reconstruction using ${ }^{13} \mathrm{C} /{ }^{12} \mathrm{C}$ ratios in animal bones. In: Price, T. D. (ed.) The Chemistry of Prehistoric Human Bone. Cambridge: Cambridge University Press, 105-125.

van Klinken, G. J., van der Plicht, H.and Hedges, R. E. M. 1994. Bone ${ }^{13} \mathrm{C} /{ }^{12} \mathrm{C}$ ratios reflect (palaeo-) climatic variations. Geophysical Research Letters, 21, 445-448.

Van Neer, W.and Parker, T. S. 2008. First archaeozoological evidence for haimation, the "invisible" garum. Journal of Archaeological Science, 35, 1821-1827.

Van Neer, W., Wildekamp, R., Waelkens, M., Arndt, A.and Volckaert, F. 2000. Fish as indicators of trade relationships in Roman times: the example of Sagalassos, Turkey. In: Mashkour, M., Choyke, A. M., Buitenhuis, H. \& Poplin, F. (eds.) International Symposium on the Archaeozoology of Southwestern Asia and Adjacent Areas (4th: 1998 : Paris, France): Archaeozoology of the Near East IVB. Proceedings of the fourth international symposium on the archaeozoology of south western Asia and adjacent areas. Groeningen: Centre for Archaeological Research and Consultancy, 206-215.

Vanderklift, M. A.and Ponsard, S. 2003. Sources of variation in consumer-diet $\square^{15} \mathrm{~N}$ enrichment: a meta-analysis. Oecologia, 136, 169-182.

Vika, E.and Theodoropoulou, T. 2012. Re-investigating fish consumption in Greek antiquity: results from $\delta^{13} \mathrm{C}$ and $\delta^{15} \mathrm{~N}$ analysis from fish bone collagen. Journal of Archaeological Science, 39, 1618-1627.

Vogel, J. C., Fuls, A.and Danin, A. 1986. Geographical and environmental distribution of $\mathrm{C}_{3}$ and $\mathrm{C}_{4}$ grasses in the Sinai, Negev, and Judean deserts. Oecologia, 70, 258-265. 
715 Watson, P. M. 2008. The Byzantine Period. In: Adams, R. B. (ed.) Jordan. An Archaeological Reader. London: Equinox, 443-482.

717 Wilkins, J. M.and Hill, S. 2006. Food in the Ancient World, Oxford, Blackwell.

718 Winter, K. 1981. C4 plants of high biomass in arid regions of Asia - Occurrence of C4 photosynthesis in Chenopodiaceae and Polygonaceae from the Middle East and USSR. Oecologia, 48, 100-106.

Zohary, D.and Hopf, M. 2000. Domestication of plants in the Old World. Third Edition, Oxford, Oxford University Press.

Zohary, M. 1973. Geobotanical foundations of the Middle East, Stuttgart, Gustav Fischer Verlag. 
Table 1. Descriptive statistics (group sizes, mean $\delta^{13} \mathrm{C}$ and $\delta^{15} \mathrm{~N}$, standard deviations and minimum and maximum values) for human and faunal samples from Ya'amūn

\begin{tabular}{cccccc}
\hline Group & $\mathbf{n}$ & $\begin{array}{c}\text { mean } \mathbf{\delta}^{13} \mathbf{C}(\%) \\
(\mathbf{m i n}-\mathbf{m a x})\end{array}$ & $\mathbf{s . d .}$ & $\begin{array}{c}\text { mean } \mathbf{\delta}^{\mathbf{1 5}} \mathbf{N}(\%) \\
(\mathbf{m i n}-\mathbf{m a x})\end{array}$ & s.d. \\
\hline MB and LB sheep/goats & 6 & $\begin{array}{c}-18.6 \\
(-20.1--16.6)\end{array}$ & 1.4 & $\begin{array}{c}8.5 \\
(5.8-11.4)\end{array}$ & 1.9 \\
\hline LR/Byz sheep/goats & 5 & $\begin{array}{c}-19.3 \\
(-20.1--19.6)\end{array}$ & 0.5 & $\begin{array}{c}5.3 \\
(4.0-6.4)\end{array}$ & 0.9 \\
\hline LR/Byz cattle & 2 & $-18.8--15.6$ & & $5.4-9.7$ & \\
\hline MB and LB humans & 15 & $\begin{array}{c}-18.8 \\
(-19.4--18.3)\end{array}$ & 0.3 & $\begin{array}{c}8.8 \\
(7.4-9.8)\end{array}$ & 0.7 \\
\hline LR/Byz humans & 17 & $\begin{array}{c}-19.1 \\
(-19.8--18.5)\end{array}$ & 0.3 & $\begin{array}{c}8.1 \\
(7.3-9.0)\end{array}$ & 0.6 \\
\hline Freshwater fish & 3 & $\begin{array}{c}-16.8 \\
(-21.5--10.3)\end{array}$ & 5.8 & $\begin{array}{c}6.9 \\
(6.1-9.3)\end{array}$ & 2.0 \\
\hline Marine fish & 2 & $\begin{array}{c}-7.2 \\
(-9.70-4.7)\end{array}$ & 3.5 & $\begin{array}{c}10.4 \\
(8.2-12.6)\end{array}$ & 3.1 \\
\hline
\end{tabular}


Ref: JASC14-754

Title: Diet and herding strategies in a changing environment: stable isotope analysis of Bronze Age and Late Antique skeletal remains from Ya'amūn, North Jordan

\section{Figure Legends}

Figure 1. Map of Jordan with sites mentioned in the text superimposed on (1.a) the modern phytogeographic zones (based on data from Zohary 1973 and Al-Eisawi 1985, redrawn from Cordova 2007, Figure P.1, and Palmer 2013, Figure I.18) and (1.b) a rainfall map of modern Jordan (redrawn from Kennedy 2007, fig. 3.4a).

Figure 2. Carbon and nitrogen isotope data of Mid- and Late Bronze Age and Late Roman/Byzantine sheep/goats from Ya'amūn. $\delta^{13} \mathrm{C}$ and $\delta^{15} \mathrm{~N}$ values of the Bronze Age sheep/goats are positively correlated (Pearson's $r=0.87, p=0.026$ ) and therefore consistent with varying consumption of plants from arid and semi-arid environments.

Figure 3. Carbon and nitrogen isotope data of Mid- and Late Bronze Age and Late Roman/Byzantine humans from Ya'amūn in comparison with mean values ( $\pm 1 \mathrm{sd})$ for sheep/goats from these time periods. The variation in human values to a large extent mirrors that observed in the fauna.

Figure 4. Carbon and nitrogen isotope data for humans (individual data) and sheep/goats (mean values $\pm 1 \mathrm{sd}$ ) from Ya'amūn in comparison with $\delta^{13} \mathrm{C}$ and $\delta^{15} \mathrm{~N}$ values for marine (one specimen each of family Scienidae and Mugilidae) and freshwater fish (two specimens of Tilapia sp. and one of Clarias (catfish)) from the same site. 


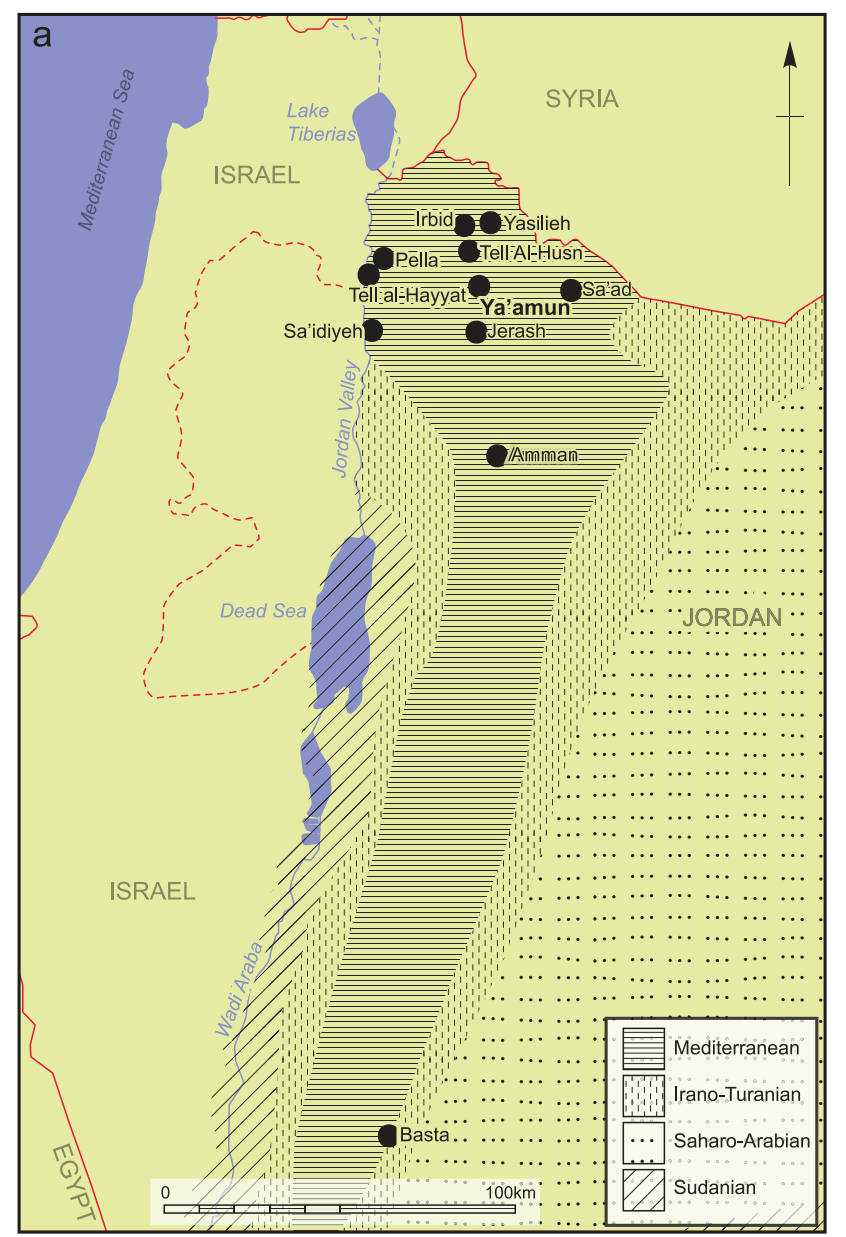




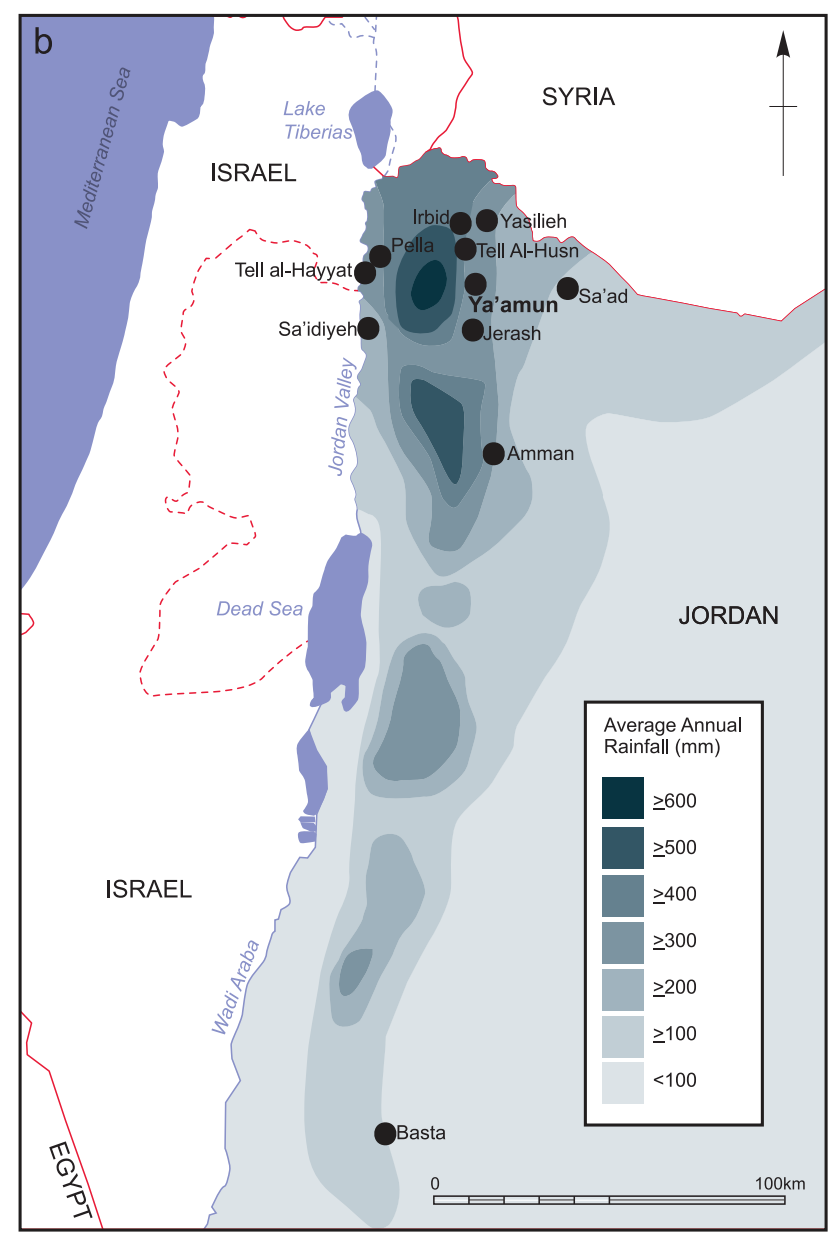




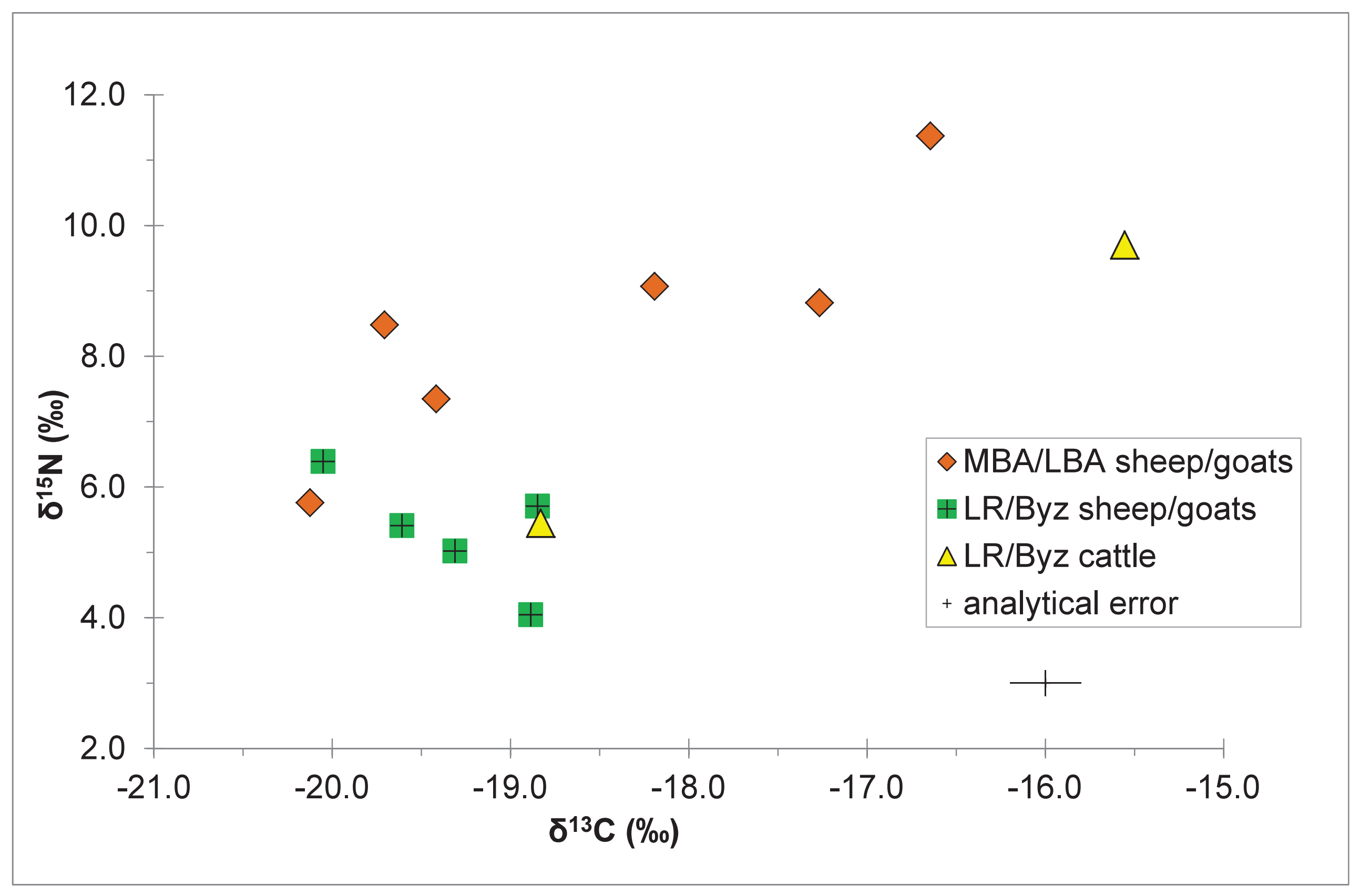




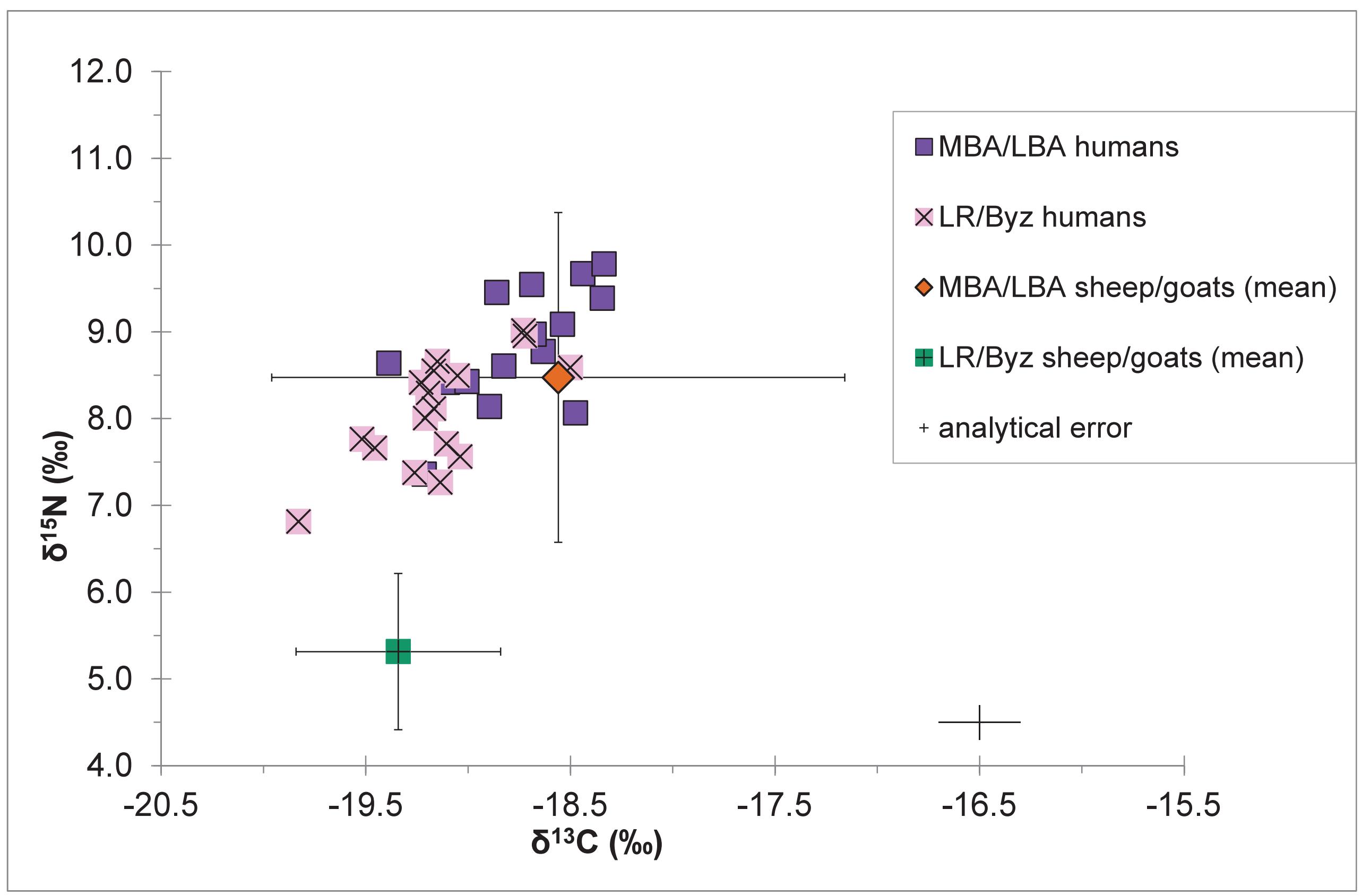




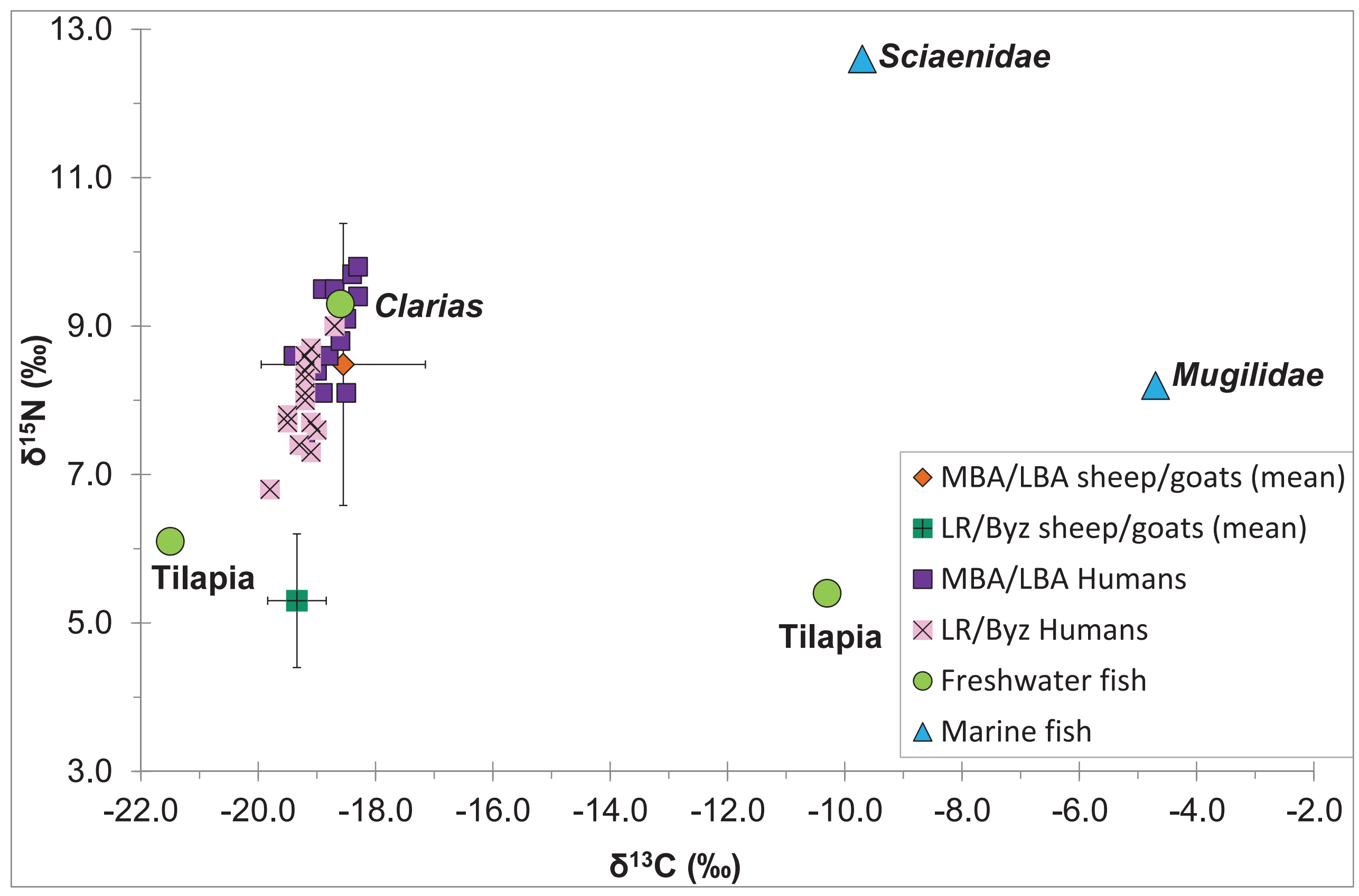


2 Diet and herding strategies in a changing environment: stable isotope analysis of

3 Bronze Age and Late Antique skeletal remains from Ya'amūn, Jordan

Sample Preparation and Analytical Methods

Cortical bone from the diaphysis of long bones, taken from areas devoid of any pathological lesions, was the preferred sampling material. Samples consisted of bone chunks weighing between 200 and $300 \mathrm{mg}$. All outer surfaces were abraded with the aid of a drill before collagen extraction was carried out following the Longin ((1971) method modified according to recommendations by Collins and Galley (1998). . Briefly, bone chunks were demineralised in $0.5 \mathrm{M}$ in the fridge for several days, after which they were rinsed to neutrality with ultrapure water (Milli-Q®). The samples were then placed in a $\mathrm{pH} 3$ $\mathrm{HCl}$ solution and gelatinised in a heater-block at 70 degrees $\mathrm{C}$ for 48 hours. Acid insoluble residues where removed with the aid of an Ezee®-filter (60-90 $\mu \mathrm{m}$, Elkay) and the remaining solutions was frozen and then freeze-dried for $48 \mathrm{~h}$. Aliquots of between 0.9 and $1.1 \mathrm{mg}$ of freeze-dried 'collagen' were weighed in duplicates into ultraclean tin capsules.

Carbon and nitrogen stable isotope compositions of samples were determined by analysis on a Europa Geo 20-20 Continuous Flow Isotope Ratio Mass Spectrometer (CF-IRMS) interfaced with Sercon® elemental analyser (EA) in the School of Human and Environmental Sciences, University of Reading, UK. All $\delta^{13} \mathrm{C}$ values are expressed relative to Pee Dee Belemnite (V-PDB) and while the $\delta^{15} \mathrm{~N}$ values are referred to atmospheric nitrogen (AIR). The analytical error was calculated from repeat analysis of internal collagen standards included in each run and was determined at $\pm 0.2 \%$ (1sd) or better for $\delta^{13} \mathrm{C}$, and $\delta^{15} \mathrm{~N}$ measurements. Internal working standards which were calibrated to internationally certified reference materials included the amino acid methionine (Elemental Microanalysis/MethR), powdered Bovine Liver Standard (NIST1577a/BLS) and a batch of pork gelatine prepared at the Reading stable isotope laboratory ("Reading Pork Gelatine"/RPG).

Collagen samples were considered of acceptable quality when having an atomic $\mathrm{C}: \mathrm{N}$ ratio between 2.9 and 3.6, \%C $\geq 13 \%$ and \%N $\geq 4.8 \%$ (Ambrose, 1990, DeNiro, 1985). Samples that yielded less than $1 \%$ collagen were still regarded as acceptable if they 
31 fulfilled these criteria and if their $\delta^{13} \mathrm{C}$ and $\delta^{15} \mathrm{~N}$ ratios were not unusual within the 32 population context (van Klinken 1999). Inferential statistics were computed with SPSS 33 v.19.

\section{$\underline{\text { References }}$}

35 Ambrose, S. H. 1990. Preparation and characterisation of bone and tooth collagen for isotopic analysis. Journal of Archaeological Science, 17, 431-451.

Collins, M.J., Galley, P. 1998. Towards an Optimal Method of Archaeological Collagen

Extraction: The Influence of pH and Grinding. Ancient Biomolecules 2: 209-222.

DeNiro, M. J. 1985. Postmortem preservation and alteration of in vivo bone collagen isotope ratios in relation to palaeodietary reconstruction. Nature, 317, 806-809. van Klinken, G.J. 1999. Bone Collagen Quality Indicators for Palaeodietary and Radiocarbon Measurements. Journal of Archaeological Science 26: 687-695. 
Table S1. Carbon and nitrogen stable isotope data and collagen quality indicators of

46 faunal bone samples from Ya'amūn. Archaeological dates are abbreviated as follows: MBA=Middle Bronze Age; LBA=Late Bronze Age; LR/Byz=Late Roman/Byzantine. Nil refers to samples which yielded no collagen for analysis.

\begin{tabular}{lcccccccc}
\hline Species & Sample Code & Date & $\mathbf{\delta}^{13} \mathbf{C}$ & $\mathbf{\delta}^{15} \mathbf{N}$ & \%C & \%N & C:N & \%Coll \\
\hline Bos & YMN fb 084 & MBA & & & & & & Nil \\
Sheep/Goat & YMN fb 085 & MBA & & & & & & Nil \\
Sheep/Goat & YMN fb 086 & MBA & -19.7 & 8.5 & 40.3 & 14.0 & 3.4 & 1.3 \\
Sheep/Goat & YMN fb 087 & MBA & -16.6 & 11.4 & 19.5 & 6.8 & 3.4 & 2.6 \\
Fish (Sciaenidae). & YMN fb 088 & MBA & -9.7 & 12.6 & 40.0 & 14.3 & 3.3 & 6.6 \\
Sheep/Goat & YMN fb 089 & MBA & -19.4 & 7.3 & 41.1 & 13.8 & 3.5 & 0.8 \\
Sheep/Goat & YMN fb 090 & MBA & & & & & & Nil \\
Sheep/Goat & YMN fb 074 & LBA & & & & & & Nil \\
Sheep/Goat & YMN fb 075 & LBA & -20.1 & 5.8 & 42.8 & 15.0 & 3.3 & 3.1 \\
Sheep/Goat & YMN fb 076 & LBA & -17.3 & 8.8 & 42.8 & 15.2 & 3.3 & 2.7 \\
Sheep/Goat & YMN fb 077 & LBA & -18.2 & 9.1 & 42.6 & 15.1 & 3.3 & 7.2 \\
Sheep/Goat & YMN fb 078 & LBA & & & & & & Nil \\
Sheep/Goat & YMN fb 092 & LR/Byz & -19.3 & 5.0 & 41.6 & 15.0 & 3.2 & 9.0 \\
Sheep/Goat & YMN T fb 093 & LR/Byz & -18.8 & 5.7 & 39.0 & 14.2 & 3.2 & 12.0 \\
Bos & YMN T fb 094 & LR/Byz & -18.8 & 5.4 & 42.3 & 15.2 & 3.3 & 3.4 \\
Bos & YMN T fb 095 & LR/Byz & -15.6 & 9.7 & 44.1 & 16.0 & 3.2 & 16.0 \\
Sheep/Goat & YMN T fb 096 & LR/Byz & -20.1 & 6.4 & 38.0 & 13.3 & 3.3 & 4.1 \\
& YMN T fb & & & & & & & \\
Sheep/Goat & 097* & LR/Byz & -18.9 & 4.0 & 43.6 & 16.0 & 3.2 & 18.2 \\
Sheep/Goat & YMN T fb 098 & LR/Byz & -19.6 & 5.4 & 41.1 & 14.7 & 3.3 & 9.2 \\
Fish (Mugilidae) & YMN T fb 099 & LR/Byz & -4.7 & 8.2 & 43.1 & 15.8 & 3.2 & 12.0 \\
Fish (Tilapia sp.) & YMN T fb 100 & LR/Byz & -21.5 & 6.1 & 43.2 & 15.7 & 3.2 & 10.0 \\
Fish (Tilapia sp.) & YMN T fb 101 & LR/Byz & -10.3 & 5.4 & 42.4 & 15.5 & 3.2 & 9.4 \\
Fish (Claridae) & YMN T fb 102 & LR/Byz & -18.6 & 9.3 & 41.2 & 14.9 & 3.2 & 6.0 \\
\hline
\end{tabular}


51 Table S2. Carbon and nitrogen stable isotope data and collagen quality indicators of 52 human bone samples from Ya'amūn. Archaeological dates are abbreviated as follows:

53 MBA=Middle Bronze Age; LBA=Late Bronze Age; LR=Late Roman; Byz= Byzantine. Nil 54 refers to samples which yielded no collagen for analysis.

\begin{tabular}{|c|c|c|c|c|c|c|c|}
\hline Sample Code & Date & $\delta^{13} \mathrm{C}$ & $\delta^{15} \mathrm{~N}$ & $\% \mathrm{C}$ & $\% \mathbf{N}$ & $\mathrm{C:N}$ & \%Coll \\
\hline YMN hb 001 & $\overline{\mathrm{MBA}}$ & -19.4 & 8.6 & 40.4 & 14.0 & 3.4 & 0.9 \\
\hline YMN hb 002 & MBA & -19.1 & 8.4 & 42.2 & 14.8 & 3.3 & 4.0 \\
\hline YMN hb 003 & MBA & -18.9 & 9.5 & 42.2 & 14.7 & 3.3 & 2.0 \\
\hline YMN hb 004 & MBA & -19.2 & 7.4 & 41.5 & 13.9 & 3.5 & 0.6 \\
\hline YMN hb 005 & MBA & & & & & & Nil \\
\hline YMN hb 006 & MBA & -19.0 & 8.4 & 41.6 & 13.5 & 3.6 & 1.3 \\
\hline YMN hb 007 & MBA & & & & & & Nil \\
\hline YMN hb 008 & MBA & & & & & & Nil \\
\hline YMN hb 009 & MBA & -18.5 & 9.1 & 41.0 & 14.6 & 3.3 & 4.3 \\
\hline YMN hb 010 & MBA & -18.3 & 9.4 & 43.4 & 15.6 & 3.2 & 9.3 \\
\hline YMN hb 011 & MBA & -18.4 & 9.7 & 43.8 & 15.7 & 3.3 & 7.5 \\
\hline YMN hb 012 & MBA & & & & & & Nil \\
\hline YMN hb 013 & MBA & -18.6 & 8.8 & 42.9 & 15.4 & 3.3 & 9.0 \\
\hline YMN hb 014 & MBA & -18.9 & 8.1 & 43.3 & 15.7 & 3.2 & 10.0 \\
\hline YMN hb 015 & MBA & -18.3 & 9.8 & 42.4 & 15.3 & 3.2 & 5.1 \\
\hline YMN hb 016 & MBA & -18.8 & 8.6 & 43.0 & 15.7 & 3.2 & 14.5 \\
\hline YMN hb 017 & LBA & & & & & & Nil \\
\hline YMN hb 018 & LBA & & & & & & Nil \\
\hline YMN hb 019 & LBA & -18.7 & 9.0 & 42.8 & 15.4 & 3.2 & 6.0 \\
\hline YMN hb 020 & LBA & & & & & & Nil \\
\hline YMN hb 021 & LBA & -18.7 & 9.5 & 42.0 & 15.1 & 3.2 & 2.8 \\
\hline YMN hb 022 & LBA & -18.5 & 8.1 & 39.0 & 13.8 & 3.3 & 4.0 \\
\hline YMN hb 023 & LR & & & & & & Nil \\
\hline YMN hb 024 & LR & -19.1 & 8.5 & 41.4 & 15.1 & 3.2 & 10.0 \\
\hline YMN hb 025 & LR & -18.7 & 9.0 & 42.8 & 15.3 & 3.3 & 10.0 \\
\hline YMN hb 026 & LR & -19.5 & 7.7 & 40.9 & 14.1 & 3.4 & 1.3 \\
\hline YMN hb $027^{*}$ & Byz & -18.5 & 8.6 & 43.0 & 15.5 & 3.2 & 17.0 \\
\hline YMN hb 028 & Byz & -19.1 & 7.3 & 38.5 & 13.5 & 3.3 & 3.5 \\
\hline YMN hb 029 & Byz & -19.3 & 7.4 & 39.1 & 13.6 & 3.4 & 3.6 \\
\hline YMN hb 030 & Byz & -19.2 & 8.0 & 35.9 & 12.5 & 3.3 & 2.6 \\
\hline YMN hb 031 & Byz & -19.8 & 6.8 & 42.0 & 14.9 & 3.3 & 3.6 \\
\hline YMN hb 032 & Byz & -19.1 & 7.7 & 43.4 & 15.3 & 3.3 & 3.3 \\
\hline YMN hb 033 & Byz & -19.5 & 7.8 & 28.9 & 9.9 & 3.4 & 3.7 \\
\hline YMN hb 034 & LR/Byz & -19.0 & 7.6 & 33.0 & 11.7 & 3.3 & 5.8 \\
\hline YMN hb 035 & LR/Byz & -19.2 & 8.6 & 38.3 & 13.5 & 3.3 & 7.2 \\
\hline YMN hb 036 & LR/Byz & & & & & & Nil \\
\hline YMN hb 037 & LR/Byz & & & & & & Nil \\
\hline YMN hb 038 & LR/Byz & -19.2 & 8.3 & 43.0 & 15.0 & 3.4 & 6.0 \\
\hline YMN hb 039 & LR/Byz & -19.2 & 8.1 & 41.6 & 14.3 & 3.4 & 4.2 \\
\hline YMN hb 040 & LR/Byz & & & & & & $\mathrm{Nil}$ \\
\hline YMN hb 041 & LR/Byz & & & & & & Nil \\
\hline YMN hb 042 & LR/Byz & & & & & & Nil \\
\hline YMN hb 043 & LR/Byz & -18.7 & 9.0 & 43.4 & 15.6 & 3.2 & 6.8 \\
\hline YMN hb 044* & LR/Byz & -19.2 & 8.4 & 43.7 & 15.7 & 3.2 & 19.5 \\
\hline YMN hb 045 & LR/Byz & -19.1 & 8.7 & 42.8 & 15.1 & 3.3 & 11.5 \\
\hline
\end{tabular}


